\title{
EFFECT OF VERMICOMPOST AND SELECTED PLANT PREPARATIONS ON THE DEVELOPMENT OF ARBUSCULAR MYCORRHIZAL SYMBIOSIS IN LETTUCE (LACTUCA SATIVA)
}

\author{
Michaela Stroblová1, Ladislava Prokopová1, Jaroslav Záhora ${ }^{1}$ \\ ${ }^{1}$ Department of Agrochemistry, Soil Science, Microbiology and Plant Nutrition, Mendel University in Brno, \\ Zemědělská 1, 61300 Brno, Czech Republic
}

\begin{abstract}
STROBLOVÁ MICHAELA, PROKOPOVÁ LADISLAVA, ZÁHORA JAROSLAV. 2018. Effect of Vermicompost and Selected Plant Preparations on the Development of Arbuscular Mycorrhizal Symbiosis in Lettuce (Lactuca Sativa). Acta Universitatis Agriculturae et Silviculturae Mendelianae Brunensis, 66(1): 195-201.

The aim of the pot experiment was to evaluate effect of vermicompost and promoting plant preparations application (Symbivit and Plantaktiv) on the development of arbuscular mycorrhizal symbiosis in lettuce, amount of extraradical mycelium of mycorrhizal fungi in soil and plant biomass production. Symbivit contains six species of mycorrhizal fungi and Plantaktiv contains magnesium sulfate activated by oxygen promoting activity of aerobic microorganisms in the soil. The application of vermicompost and promoting plant preparations did not have a statistically significant effect on lettuce root colonization by mycorrhizal fungi. The greatest length of extraradical mycelium was observed in variant with vermicompost application, in variant with addition of vermicompost and Symbivit, and in variant with vermicompost applied with both plant preparations. There was detected statistically significant difference when compared to control variant. Dry matter weight of aboveground biomass and root of the lettuce were statistically significantly increased in all variants, where vermicompost was applied, either alone or in combination with plant preparations. Separate application of Symbivit or Plantaktiv did not have a statistically significant effect either on the length of extraradical mycelium or dry matter weight of the lettuce.
\end{abstract}

Keywords: vermicompost, plant preparations, arbuscular mycorrhiza, extraradical mycelium, root colonization, plant biomass

\section{INTRODUCTION}

The term mycorrhiza refers to a specific symbiotic relationship that is formed between the roots of higher plants and soil fungi. The most widespread type of mycorrhiza is arbuscular mycorrhizal symbiosis occurring approximately in $95 \%$ of plant species (Gryndler et al. 2004). Arbuscular mycorrhiza is made up by the great majority of cultivated plants thus, its research is of considerable practical importance. Arbuscular mycorrhizal fungi (AM fungi) improve plant uptake of water and nutrients, especially phosphorus, but also nitrogen, potassium, calcium and magnesium (Liu et al. 2002; Sedláček et al. 2013). Plants colonized by mycorrhizal fungi also exhibit superior resistance against different abiotic and biotic stress factors (Al-Garni, 2006; Khaosaad et al. 2007; Javaid and Riaz, 2008). Given the importance of mycorrhiza for nutrition and plant health, there have long been afford to find ways to support the creation of this symbiosis in agricultural, forestry or horticultural management. One of the ways to support the creation of a functional symbiotic relationship between a fungi and the plant could be posed by application of vermicompost or various supporting plant preparations into soil. Vermicompost is microbiologically active, nutrient-rich organic fertilizer formed by mutual actions of earthworms and mesophilic microorganisms. 
While microorganisms decompose organic matter via biochemical processes, earthworms act as a mechanical "mixers" which comminute organic material and change its physical and chemical properties. The result is a smooth, stable, peat-like material with a low C:N ratio, high porosity and high water holding capacity, containing nutrients in a form accessible to plants. Vermicompost has a different structure of microbial community compared to the initial organic material. Despite the lower amount of biomass and diversity of microorganisms, there is increased metabolic activity of microorganisms. Applications of such microbiologically active organic material into the soil can significantly affect soil microbial properties and subsequent plant growth (Lazcano and Domínguez, 2011). Usage of organic fertilizers (including different types of composts) is essential for sustainable soil fertility (Plošek et al. 2017).

The aim of the paper was to assess effect of vermicompost and two promoting plant preparations on development of arbuscular mycorhizal symbiosis in lettuce, amount of extraradical mycelium of mycorrhizal fungi in soil, and plant biomass production.

\section{MATERIAL AND METHODS}

The pot experiment started in October 2014. Soil was sampled in Březová nad Svitavou, sieved through a sieve with grid size of $4 \mathrm{~mm}$ and filled into the pots (volume $1 \mathrm{l}$ ) according to experimental variants. Physical and chemical properties of the sampled soil are displayed in Tab. I.

Pot experiment comprised the following variants: control (C); application of vermicompost (V); application of Symbivit (S); application of Plantaktiv (P); application of vermicompost and Symbivit $(\mathrm{V}+\mathrm{S})$; application of vermicompost and Plantaktiv $(\mathrm{V}+\mathrm{P})$; application of Symbivit and Plantaktiv $(\mathrm{S}+\mathrm{P})$; and application of vermicompost and Symbivit and Plantaktiv $(\mathrm{V}+\mathrm{S}+\mathrm{P})$. Each variant was repeted
3 times. The lettuce (Lactuca sativa, variety Maraton) was used as a model plant.

Vermicompost was applied to the soil before sowing in amount of $50 \mathrm{ml}$ per one pot (this corresponds to $24 \mathrm{t}$ of vermicompost per ha). It is an organic fertilizer that is produced by activity of Californian Red Earthworms (Eisenia fetida). Vermicompost was produced by company Karel Pecl - EKOVERMES, Pustějov, Czech Republic. Physical and chemical properties of vermicompost given by the manufacturer are shown in Tab. II.

Symbivit was applied to the soil before sowing in amount of $15 \mathrm{~g}$ per one pot. It is a promoting plant product containing reproductive parts of 6 species of mycorrhizal fungi (spores, colonized parts of the roots), natural clay carriers and natural ingredients supporting mycorrhiza (humates, seaweed extracts, grinded rock). Symbivit product is manufactured by Symbiom Ltd., Lanškroun, Czech Republic.

Plantaktiv was applied to the soil in form of solution at stage of 3 true leafs of the plants. Its amount applied was $0.1 \mathrm{~g}$ in $40 \mathrm{ml}$ of demineralised water per a pot. Plantaktiv is a supportive plant product containing magnesium sulfate activated by oxygen which promotes activity of aerobic microorganisms in the soil. Plantaktiv product is manufactured by company BioActive $\mathrm{GmbH}$, Würchwitz, Germany.

In order determine the length of extraradical mycelium of AM fungi in the soil, two $45^{\circ}$ circle sectors of Pragopor nitrocellulose membrane filter (diameter of $50 \mathrm{~mm}$, pore size $0.6 \mu \mathrm{m}$ ) were vertically inserted into each pot prior to sowing the seeds. Membrane filters were placed radially towards the centre of the pot, $2.5 \mathrm{~cm}$ under the soil surface. Filters are manufactured by Pragochema Ltd., Prague, Czech Republic.

In each pot, 3 seeds of lettuce were planted. After germination, one plant was left in the pot. For 34 days, the experimental pots were placed into phytotron with controlled temperature and illumination (Biotechnology pavilion M, Mendel

I: Physical and chemical properties of the soil taken in Březová nad Svitavou (Plošek, 2016)

\begin{tabular}{|c|c|}
\hline Soil properties & Value \\
\hline $\mathrm{pH} / \mathrm{CaCl}_{2}$ & 5.84 \\
\hline $\mathrm{C}_{\text {tot }}\left(\mathrm{g} \cdot \mathrm{kg}^{-1}\right)$ & 17.7 \\
\hline $\mathbf{N}_{\text {tot }}\left(\mathrm{g} \cdot \mathrm{kg}^{-1}\right)$ & 1.6 \\
\hline $\mathrm{C}_{\text {org }}\left(\mathrm{g}^{\mathrm{kgg}} \mathrm{kg}^{-1}\right)$ & 11.3 \\
\hline Humus content (\%) & 1.95 \\
\hline $\mathbf{P}\left(\mathbf{m g} \cdot \mathrm{kg}^{-1}\right)$ & 181 \\
\hline $\mathrm{K}\left(\mathrm{mg} \cdot \mathrm{kg}^{-1}\right)$ & 168 \\
\hline $\mathrm{Ca}\left(\mathrm{mg} \cdot \mathrm{kg}^{-1}\right)$ & 1449 \\
\hline $\operatorname{Mg}\left(\mathrm{mg} \cdot \mathrm{kg}^{-1}\right)$ & 53 \\
\hline C:N & 19.8 \\
\hline $\mathrm{CaCO}_{3}\left(\mathrm{~g} \cdot \mathrm{kg}^{-1}\right)$ & 1.1 \\
\hline Combustibles (\%) & 3.16 \\
\hline
\end{tabular}


II: Physical and chemical properties of vermicompost (Karel Pecl-EKOVERMES)

\begin{tabular}{lc}
\hline \multicolumn{1}{c}{ Vermicompost properties } & Value \\
\hline Moisture (\%) & 30 \\
Combustibles (\%) & 35 \\
Total N (\% DM) & 2.2 \\
Total P (\% DM) & 2.5 \\
Total K (\% DM) & 2.3 \\
pH & 7.1 \\
C:N & 9 \\
Cd (mg.kg-1 DM) & 9 \\
Pb (mg.kg-1 DM) & 1 \\
Zn (mg.kg-1 DM) & 19 \\
\hline
\end{tabular}

$\mathrm{DM}$ - dry matter

University) and were watered regularly with demineralized water.

Immediately after the harvest, $0.5 \mathrm{~g}$ of fresh root mass was collected for the determination of mycorrhizal colonization. The roots were thoroughly washed and stored in the fixing FAA solution ( $50 \%$ ethanol, acetic acid, formaldehyde). To evaluate mycorrhizal colonization, the roots were stained with $0.05 \%$ trypan blue in lactoglycerol (Koske and Gemma, 1989) and the percentage of roots colonized by AM fungi was determined microscopically using modified preparation method (Giovanneti and Mosse, 1980). Remaining roots and aboveground biomass of lettuce were dried at $60{ }^{\circ} \mathrm{C}$ to constant weight and their weigh was noted.

Extraradical mycelium of AM fungi was extracted from soil by the inserted membrane method (Baláž and Vosátka, 2001). Membrane filters, which had been inserted into the soil at the beginning of the experiment, were carefully removed and the grown mycelium was stained with $0.05 \%$ trypan blue in lactoglycerol (Koske and Gemma, 1989). 12 micrographs were taken in each $45^{\circ}$ circle sector of the membrane filter using a light microscope Olympus CX-41 and Digital Camera Olympus
C-3040ZOOM and were processed by Adobe Photoshop CS5 software. Each micrograph was covered with a square grid with an edge length of elementary squares of $170 \mu \mathrm{m}$ and length of mycelia was determined by gridline intersect method (Giovanneti and Mosse, 1980). The resulting values were converted to $1 \mathrm{~cm}^{2}$ of the membrane filter.

Results were statistically evaluated by one-way analysis of variance combined with Tukey's HSD test at significance level of $\mathrm{P}<0.05$. The evaluation was performed in Statistica 10 (StatSoft Inc., Tulsa, USA).

\section{RESULTS AND DISCUSSION}

The root colonization of the lettuce by AM fungi ranged between 43-58\% on average. Applying vermicompost and supportive plant preparations more or less increased the colonization of plant roots by mycorrhizal fungi compared to the control variant. Anyway, the difference was not statistically conclusive. Higher percentage of colonized roots was shown by variants amended with vermicompost, either alone or in combination with plant preparations (Fig. 1). Cavender et al. (2003) and Hameeda et al. (2007), who observed the effects of vermicompost

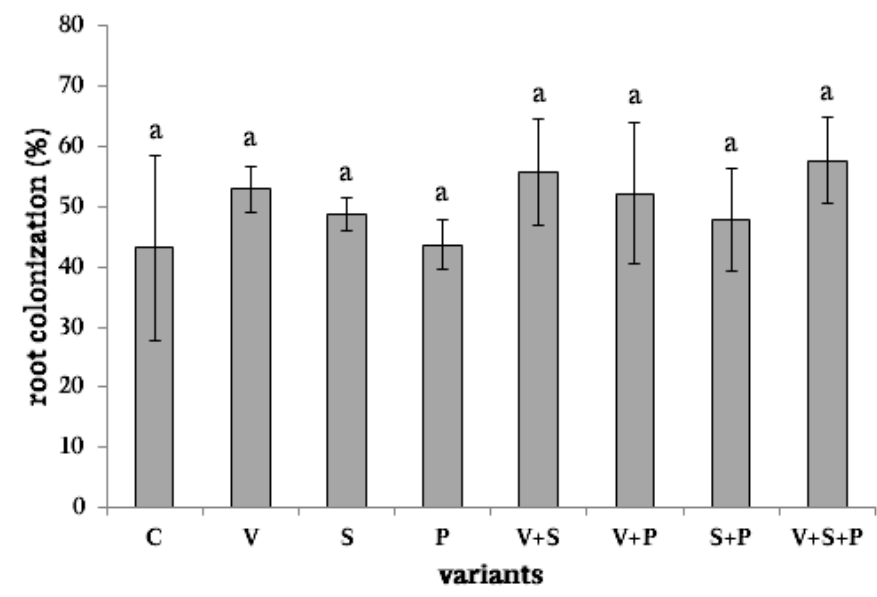

1: Root colonization of lettuce by AM fungi. Columns shows mean values \pm standard deviation ( $n=3)$. Columns indicated by different letters are statistically significantly different $(P<0.05)$. Indication of variants: $C$ - control, $V$ - vermicompost, $S$ - Symbivit, $P$ - Plantaktiv. 
on the development of mycorrhizal symbiosis in sorghum, found a higher percentage of colonized roots in plants where vermicompost was applied. Cavender et al. (2003) state mycorrhizal fungi can be stimulated by the nutrients contained in vermicompost, directly or indirectly by nutrients stimulating the growth of the host plant roots. Other substances contained in the vermicompost, such as growth regulators or metabolites arising from the activity of earthworms and microorganisms, can have similar effect (Joshi et al. 2015).

The length of the extraradical mycelium of AM fungi varied between $9-34 \mathrm{~cm} \cdot \mathrm{cm}^{-2}$ of the membrane filter. Also in this case, the application of vermicompost and plant preparations increased the mycelium length of mycorrhizal fungi compared to the control variant. The largest length of extraradical mycelium was found in variants with vermicompost (V), vermicompost with Symbivit $(\mathrm{V}+\mathrm{S})$, and in vermicompost with both plant preparations $(\mathrm{V}+\mathrm{S}+\mathrm{P})$. Those were statistically significantly different from the control variant. In the other variants, the increase in the length of the extraradical mycelium was not statistically significant (Fig. 2). Even in this case, the growth of extraradical mycelium of mycorrhizal fungi could be stimulated by substances contained in vermicompost, as mentioned above. Even Sabbagh et al. (2017) found that the application of vermicompost had a positive effect not only on mycorrhizal colonization of wheat roots but also on the development of extraradical hyphae of mycorrhizal fungi in soil. Roldán et al. (2006) state the addition of organic matter in the form of compost promotes the growth of hyphae of arbuscular mycorrhizal fungi. AM fungi search for soil organic particles which they colonize by mycelium (StJohn et al. 1983). It is also possible that arbuscular mycorrhizal fungi can absorb some organic substances from the environment by mycelium since the regular additions of small amounts of sugar into non-sterile soil were found out to significantly promote mycelium growth
(Gryndler et al. 2004). In turn, Enkhtuya (2005) states that some specific soil conditions, such as increased aeration or improved water regime, can stimulate the development of extraradical mycelium. A significant increase in total soil porosity and water holding capacity after vermicompost application was found by Hidalgo and Harkess (2002) and Hidalgo et al. (2006).

The positive effect of the vermicompost was also expressed by dry matter weight of lettuce biomass. In all variants where vermicompost was applied, either alone or in combination with plant preparations, the dry matter weight of aboveground biomass and roots statistically increased not only when compared to the control but also to other variants. The separate application of Symbivit or Plantaktiv did not have a statistically significant effect on the dry matter weight of lettuce (Fig. 3). Stimulation of plant growth after application of vermicompost has been found in a wide range of plant species (Lazcano and Domínguez, 2011). Vermicompost is a source of macro- and micronutrients for plants. Some of them are in inorganic form, which is readily available for plants, but most are released gradually through the mineralization of organic matter (Chaoui et al., 2003). Growth of plants can be indirectly affected by microorganisms present in vermicompost or soil microorganisms whose populations and activity greatly increase after vermicompost addition. It is known that microorganisms produce substances regulating plant growth, such as auxins, cytokinins or gibberellins (Arancon et al., 2005). Muscolo et al. (1999) report humic substances contained in vermicompost may have similar effects as auxins. This is confirmed by Atiyeh et al. (2002) who monitored effects of humic acids extracted from vermicompost on the growth of tomato and cucumber plants. They found humic acids significantly increased growth both of them in height, surface area and dry matter of aboveground biomass and roots, irrespective of the nutrients availability in the soil.

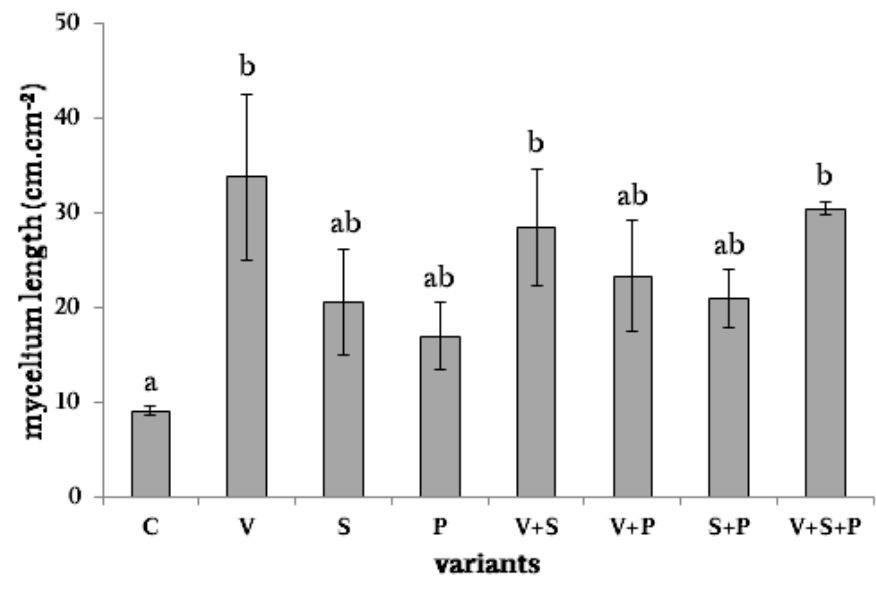

2: Length of extraradical mycelium of AMfungi in soil. Columns shows mean values \pm standard deviation ( $n=3)$. Columns indicated by different letters are statistically significantly different $(P<0.05)$. Indication of variants: $C$ - control, $V$ - vermicompost, $S-S y m b i v i t, P-P l a n t a k t i v$. 


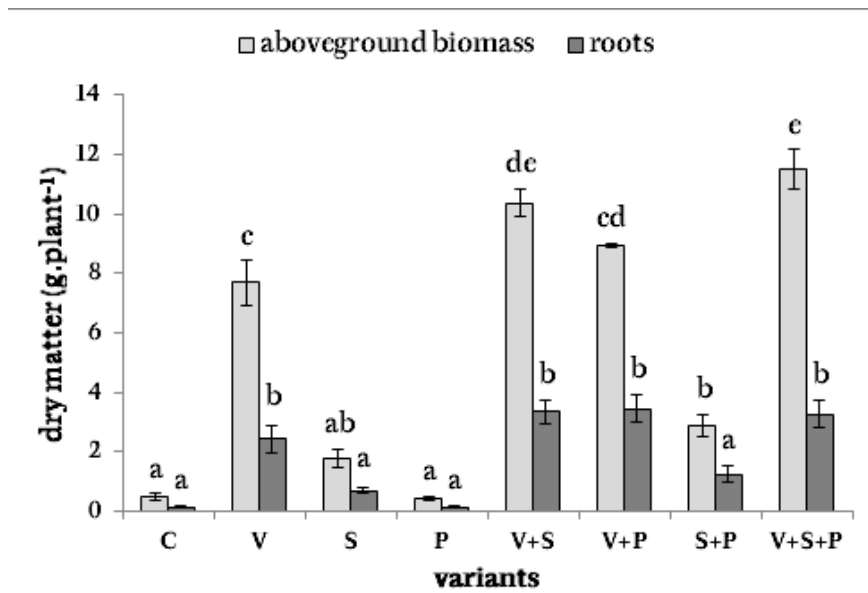

3: Dry matter weight of aboveground biomass and roots of lettuce. Columns show mean values \pm standard deviation ( $n=3$ ). Columns for aboveground biomass or roots indicated by different letters are statistically significantly different $(P<0.05)$. Indication of variants: C-control, V-vermicompost, S-Symbivit, P-Plantaktiv.

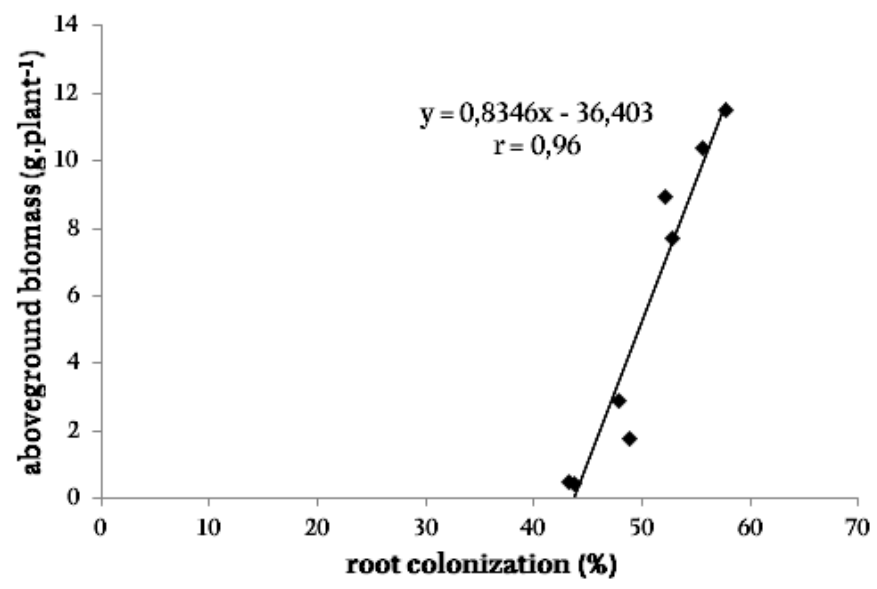

4: Correlation between mycorrhizal colonization of lettuce roots and dry matter weight of lettuce aboveground biomass. The regression equation and the Pearson correlation coefficient are displayed.

The results confirmed very strong linear dependence between the dry matter weight of the lettuce aboveground biomass and mycorrhizal root colonization (correlation coefficient $\mathrm{r}=0.96$ ) meaning lettuce, where roots were colonized by mycorrhizal fungi more, created larger amount of aboveground biomass and vice versa (Fig. 4). It is well known that root colonization by mycorrhizal fungi has a positive effect on plant growth (Millar and Ballhorn, 2013). The increase in plant production resulting from the mycorrhizal association is often directly or indirectly attributed to improving the nutritional state of the plants. Siddiqui and Mahmood (2001) report arbuscular mycorrhizal fungi improve growth and plant yields primarily due to increased phosphorus, microelement and water uptake.

\section{CONCLUSION}

The application of vermicompost and promoting plant preparations did not have a statistically significant effect on lettuce root colonization by mycorrhizal fungi. The greatest length of the extraradical mycelium was found in 3 variants (vermicompost, vermicompost with Symbivit, and vermicompost with both plant preparations). They statistically significantly differed from the control variant. The dry matter weight of lettuce aboveground biomass and roots was statistically significantly increased in all variants where vermicompost was applied, either alone or in combination with plant preparartions. The separate application of Symbivit and Plantaktiv had a statistically significant effect neither on the length of the extraradical mycelium nor the dry matter weight of the lettuce. 
Acknowledgement

This work was supported by Ministry of Agriculture, Czech Republic, National Agency for Agricultural Research, Project QJ1220007: "The possibilities for reretention of reactive nitrogen from agriculture in the most vulnerable infiltration area of water resources".

\section{REFERENCES}

AL-GARNI, S. M. S. 2006. Increased heavy metal tolerance of cowpea plants by dual inoculation of an arbuscular mycorrhizal fungi and nitrogen-fixer Rhizobium. African J. Biotech., 5(2): 133-142.

ARANCON, N. Q., EDWARDS, C. A., BIERMAN, P. et al. 2005. Effects of vermicomposts produced from cattle manure, food waste and paper waste on the growth and yields of peppers in the field. Pedobiologia, 49(4): 297-306.

ATIYEH, R. M., LEE, S., EDWARDS, C. A. et al. 2002. The influence of humic acids derived from organic wastes on plant growth. Biores. Technol., 84(1): 7-14.

BALÁŽ, M. and VOSÁTKA, M. 2001: A novel inserted membrane technique for studies of mycorrhizal extraradical mycelium. Mycorrhiza, 11(6): 291-296.

CAVENDER, N. D., ATIYEH, R. M. and KNEE, M. 2003. Vermicompost stimulates mycorrhizal colonization of roots of Sorghum bicolor at the expence of plant growth. Pedobiologia, 47(1): 85-89.

CHAOUI, H. I., ZIBILSKE, L. M. and OHNO, T. 2003. Effects of earthworm casts and compost on soil microbial activity and plant nutrient availability. Soil Biology and Biochemistry, 35(2): 295-302.

ENKHTUYA, B. 2005. Influence of arbuscular mycorrhizal symbiosis on ecophysiology of trees and grass in disturbed ecosystems. Ph.D. Thesis. Charles University, Faculty of Science, Department of Plant Physiology.

GIOVANNETI, M. and MOSSE, B. 1980. An evaluation of techniques for measuring vesicular-arbuscular mycorrhizal infection in roots. New Phytologist, 84(3): 489-500.

GRYNDLER, M., BALÁŽ, M., HRŠELOVĀ, H. et al. 2004. Mycorrhizal symbiosis - The coexistence of fungi with plant roots [in Czech: Mykorhizní symbióza - O soužití hub s kořeny rostlin]. 1st Edition. Prague: Academia.

HAMEEDA, B., HARINI, G., RUPELA, O. P. et al. 2007. Effect of composts or vermikomposts on sorghum gowth and mycorrhizal colonization. African Journal of Biotechnology, 6(1): 9-12.

HIDALGO, P. R. and HARKESS, R. L. 2002. Earthworm casting as a substrate amendment for chrysanthemum production. Hortscience, 37(7): 1035-1039.

HIDALGO, P. R., MATTA, F. B. and HARKESS, R. L. 2006. Physical and chemical properties of substrates containing earthworm castings and effects on marigold growth. HortScience, 41: 1474-1476.

JAVAID, A. and RIAZ, T. 2008. Mycorrhizal colonisation in different varieties of gladiolus and its relation with plant vegetative and reproductive growth. Int. J. Agric. Biol., 10(3): 278-282.

JOSHI, R., SINGH, J. and VIG, A. P. 2015. Vermicompost as an effective organic fertilizer and biocontrol agent: Effect on growth, yield and quality of plants. Reviews in Environmental Science and Bio/Technology, 14(1): 137-159.

KHAOSAAD, T., GARCIA-GARRIDO, J. M., STEINKELLNER, S. et al. 2007. Take-all disease is systematically reduced in roots of mycorrhizal barley plants. Soil Biol. Biochem., 39(3): 727-734.

KOSKE, R. E. and GEMMA, J. N. 1989. A modified procedure for staining roots to detect VA mycorrhizas. Mycological Research, 92(4): 486-488.

LAZCANO, C. and DOMÍNGUEZ, J. 2011. The use of vermicompost in sustainable agriculture: Impact on plant growth and soil fertility. In: MOHAMMAD, M. (Ed.). Soil Nutrients. Nova Science Publishers.

LIU, A., HAMEL, C., ELMI, A., et al. 2002. Concentrations of K, Ca and Mg in maize colonised by arbuscular mycorrhizal fungi under field conditions. Can. J. Soil Sci., 82(3): 271-278.

MILLAR, J. A. and BALLHORN, D. J. 2013. Effect of mycorrhizal colonization and light limitation on growth and reproduction of lima bean (Phaseolus lunatus L.). J. Appl. Bot. Food Qual., 86: 172-179.

MUSCOLO, A., BOVALO, F., GIONFRIDDO, F. et al. 1999. Earthworm humic matter produces auxin-like effects on Daucus carota cell growth and nitrate metabolism. Soil Biol. Biochem., 31(9): 1303-1311.

PLOŠEK, L. 2016. The soil application of treated biodegradable waste in combination with mineral fertilizers [in Czech: Aplikace zpracovaného biologicky rozložitelného odpadu vkombinaci s průmyslovými hnojivy do půdy]. Ph.D. Thesis. Mendel University in Brno. Faculty of Agronomy. Department of Agrochemistry, Soil Science, Microbiology and Plant Nutrition. Brno: MENDELU.

PLOŠEK, L., ELBL, J., LOŠÁK, T. et al. 2017. Leaching of mineral nitrogen in the soil influenced by addition of compost and N-mineral fertilizer. Acta Agriculturae Scandinavica Section B: Soil and Plant Science, 67(7): 607-614.

ROLDÁN, A., CARRASCO, L. and CARAVACA, F. 2006. Stability of desiccated rhizosphere soil aggregates of mycorrhizal Juniperus oxycedrus grown in a desertified soil amended with a composted organic residue. Soil Biology and Biochemistry, 38(9): 2722-2730.

SABBAGH, S. K., POORABDOLLAH, A., SIROUSMEHR, A. et al. 2017. Bio-fertilizers and systemic acquired resistance in fusarium infected wheat. J. Agr. Sci. Tech., 19(2): 453-464. 
SEDLÁČEK, M., PAVLOUŠEK, P., LOŠÁK, T. et al. 2013. The effect of arbuscular mycorrhizal fungi on the content of macro and micro elements in grapevine (Vitis vinifera L.) leaves. Acta Universitatis Agriculturae et Silviculturae Mendelianae Brunensis, 61(1): 187-191.

SIDDIQUI, Z. A. and MAHMOOD, I. 2001. Effect of rhizobacteria and root symbionts on the reproduction of Meloidogyne javanica and growth of chickpea. Bioresource Technology, 79(1): 41-45.

ST.JOHN, T. V., COLEMAN, D. C. and REID, C. P. P. 1983: Association of vesicular-arbuscular mycorrhizal hyphae with soil organic particles. Ecology, 64(4): 957-959.

michaela.stroblova@mendelu.cz 